\title{
Gacaca Courts: Between Fantasy and Reality
}

\author{
Jacques Fierens*
}

\begin{abstract}
Faced with an overflowing caseload and imperatives of national reconciliation, Rwandan authorities have established a system of traditional justice, meted out through gacaca courts under the legal framework created by organic laws. The following contribution analyses this framework, within the context of national and international legal systems, and pinpoints the shortcomings of the proposed form of justice. These include legal issues such as the problem of retroactivity, as well as the definition of crimes and concerns over due process and the right to a fair trial for defendants. Practical and material obstacles arise in implementing the organic laws, alongside broader implications owing to the traditional nature of such courts and possible interference by political authorities. In this respect, the gacaca courts may be victims of their own ambitions, by seeking to respond to judicial, societal and philosophical concerns alike.
\end{abstract}

\section{The Context}

\section{A. Qualifying the Irrational}

The Rwandan genocide is only just beginning to be addressed. As with all instances of 'radical evil', in the Kantian words often used to refer to crimes against humanity, ${ }^{1}$ it inevitably defies rational discourse. The innocent victims, whose mere existence was their only crime, and the perpetrators' terrifying and ongoing disregard for them ${ }^{2}$ prove beyond doubt that evil is irrational. As Primo Levi wrote with regard to Nazi extermination camps, "what happened cannot be understood, and, even, should not be understood; to understand is

* Professor at the Facultés universitaires Notre-Dame de la Paix in Namur and at the University of Liege; [jacques.fierens@fundp.ac.be]. This article was translated from French by Elsa Gopala.

1 See E. Kant, Essai sur le mal radical, in Berlinische Monatschrift, 1792. Hannah Arendt refers to radical evil in the context of concentration camps. See H. Arendt, Les origines du totalitarisme. Le système totalitaire, French translation by J.-L. Bourget, R. Davreu and P. Lévy (Paris: Seuil [Points Essais no. 307], 1972), 180.

2 See J. Hatzfeld, Une saison de machettes. Récits (Paris: Seuil, 2003). 
almost to justify it. ${ }^{3}$ Explaining evil as such is unconscionable. Explaining a crime muffles its violence. Any lawyer knows that. One is reduced to a phenomenology of horror-a description of the unfathomable.

Such description is not solely the necessary application of the law, it is not exclusively geared towards constructing the historian's discourse, it is not merely the object of psychologists' and ethnologists' study. It inevitably raises ontological issues that the lawyer ignores as irrelevant to his own purposes, but they crop up incessantly. ${ }^{4}$ The lawmaker and the judge, the legal theorist or practitioner-must they not necessarily take the irrational into account to fully grasp the facts? The commission of a genocide raises both issues with regard to the very meaning of the rule as well as its enforcement. ${ }^{5}$ Lawyers are confronted with a specific description, using legal terms, of what occurred, to qualify the facts. Legal discourse itself falls short, and crimes such as 'genocide' and 'crimes against humanity' ${ }^{6}$ had to be invented, to express the unthinkable and confer legal quality. That which could not be named had to be.

\section{B. To Judge Regardless?}

The sheer number of futile deaths was so high that even today, its numbers are uncertain to the nearest 100,000. Ten years later, mass graves continue to be uncovered on a daily basis. For the first time in the history of humanity, the perpetrators' belonging to a particular national or political group is not clearly identified, unlike the Romans vis-à-vis the Carthaginians, the young Turkish government vis-à-vis Armenians, or Nazis vis-à-vis the Jews. Further, no other genocide has torn apart the social fabric to this extent, as those in power mobilized an unprecedented majority of the civilian population against a minority which often included neighbours, friends and relatives. They tortured and killed, upon the authorization, encouragement and reassurance of leaders, i.e. in Rwanda, by the legal system.

3 P. Levi, Si c'est un homme, French translation by M. Schruoffeneger (Paris: Juliard [Pocket no. 3117], 1987), Appendix, 211, emphasis added. See also: 'Notre sagesse, c'était de ne pas chercher à comprendre' ('We were wise not to try understanding'), at 124.

4 A long philosophical tradition, dating from Parmenid, presents evil as the lack of being and reason, even though certain authors, such as Leibniz, attempt to view it as rational.

5 See, on this issue, A. Garapon, Des crimes quion ne peut ni punir ni pardonner (Paris: Odile Jacob, 2002).

6 See J. Fierens, 'La non-définition des crimes contre l'humanité, La revue nouvelle (March 2000, no. 3) 36-49. The Statute of the International Military Tribunal at Nuremberg included the prohibition of 'crimes against humanity', although 'genocide' is not expressly referred to. Only the Convention on the Prevention and Punishment of the Crime of Genocide of 9 December 1948 introduced the incrimination in international law. See, on the development of this concept, W.A. Schabas, Genocide in International Law (Cambridge: Cambridge University Press, 2000), particularly at 14 ff. See also J. Fierens, 'La qualification de génocide devant le Tribunal pénal international pour le Rwanda et devant les juridictions rwandaises', 6 Actualité du droit international humanitaire. Les dossiers de la Revue de droit pénal et de criminologie (2001) 181-209. 
Such was the challenge the new Rwandan government faced at the end of 1994. There is no greater dawn for human justice than punishing the crime of crimes, committed by tens of thousands of individuals who, for the most part, once again lived alongside their victims or the mass graves they had abandoned after their 'work' was done, in a country where the horror ceased only with the use of force and where the war had destroyed the judiciary's human and material resources.

State structures, including courts, had been annihilated. Prior to April 1994, the judicial system bore serious defects. In a report published at the end of 1992, a commission composed of magistrates and staff from the Ministry of Justice denounced the insufficient number of judges, lack of adequate training and material resources, and the dependence of the judiciary on the executive power. What remains to be said of the judicial system after the massacres? Prisons, dungeons, improvised detention centres (such as containers buried in the ground) are filled with hundreds, thousands, hundreds of thousands of detainees, some of whom are almost certainly guilty and others almost certainly innocent. According to the Interior Ministry, there were already about 60,000 detainees in 1995, 90 per cent of them male. ${ }^{7}$ Trials had to be conducted.

The establishment of a sort of 'Truth and Reconciliation Commission', based on the South African experiment, was rejected as allowing impunity, which was blamed in the first place for the events leading up to the paroxysm in 1994. The will to bring all perpetrators before a judge 'departed from the practice of previous governments. Concerning other massacres, which bore resemblance to the repetition of an announced genocide, political authorities had refused to prosecute identified perpetrators or had rushed to grant them amnesty, thus perpetuating impunity.8

7 With the return of refugees and subsequent denunciations, this number rose to 120,000 in 1998. See 'Lawyers without Borders', Annual Report (1999). On the specific nature of crimes committed by women during the genocide, as well as their status as victims, see J. Fierens (ed.), Femmes et génocide. Le cas du Rwanda: Actes du colloque organisé par le Centre Droits fondamentaux \& lien social de Namur le 20 septembre 2002 (Bruxelles: La Charte, 2003).

8 F. Mutagwera, 'Détentions et poursuites judiciaires au Rwanda', in J.-F. Dupaquier (ed.), La justice internationale face au drame rwandais (Paris: Karthala, 1996), 17. Following the first outbursts of so-called 'interethnic' violence in 1959, 1,242 individuals were prosecuted; 94 were acquitted; 244 convicted and sentenced to imprisonment for a year or less; 773 to one to five years; 90 to five to 10 years, 39 to over 10 years; and two were sentenced to death. These convictions took place before independence, while Rwanda was under Belgian protectorate. The Belgian authorities decided to grant amnesty to individuals who had committed political crimes between 1 October 1959 and 1 April 1961 (Decree-Law no. 01/188 of 31 May 1961, BORU (1961), 997). Amnesty was not granted to those who had committed assassination, murder, arson leading to death, bodily torture and attacks aimed at devastation, massacre or looting, if the imposed sentence involved a five-year prison sentence. Accusations of impunity were therefore justified. For further details, see F. Digneffe and J. Fierens (eds), Justice et gacaca: L'expérience rwandaise et le génocide (Namur: Presses universitaires de Namur, 2003), 35-36. 


\section{Rwandan Laws Concerning Genocide and Crimes Against Humanity}

Rwandan law was wholly unequipped for the situation. As in many other countries, the Convention on the Prevention and Punishment of the Crime of Genocide of 9 December 1948, ratified by Rwanda in 1975, ${ }^{9}$ had not been implemented in domestic law and no specific sentence was established for the repression of genocide or crimes against humanity. ${ }^{10}$ Organic law no. 08/96 of 30 August 1996, on the organization of prosecution for offences constituting the crime of genocide or crimes against humanity committed since 1 October 1990, was promulgated in this context. ${ }^{11}$ The new leaders having often lived in Uganda or Anglo-Saxon countries, this law was strongly influenced by principles of common law (such as plea-bargaining, guilty pleas and the comparatively lesser importance of written evidence), which neither the population nor the handful of remaining professional judges and lawyers were accustomed to. For obvious historical reasons, written law in Rwanda was largely drawn on the Roman-Germanic tradition. The civil law-common law divide therefore grafted itself onto the existing dualism between custom and written law.

The main weakness of the new law proved to be the slow pace of its implementation. Despite practices envisioned for the 'specialized chambers' established by the law, such as 'itinerant' hearings and 'group trials', and while prisons continued to brim over, 346 accused were tried in 1997, 928 in $1998,1,318$ in 1999, 2,458 in 2000, 1,416 in 2001 and 727 in 2002, or a total of 7,181 in six years. The task was daunting: at this rate, trying all the detainees would take decades, without counting those who might be implicated in the trials to come. This is still very much part of the debate: if the number of victims is indeed 1,000,000, how many perpetrators, co-perpetrators and

9 Decree-Law no. 08/75 of 12 February 1975, approving and ratifying various international treaties on human rights, disarmament, prevention and repression of certain acts likely to endanger peace among human beings and nations.

10 Article 5 provides: 'The Contracting Parties undertake to enact, in accordance with their respective Constitutions, the necessary legislation to give effect to the provisions of the present Convention, and, in particular, to provide effective penalties for persons guilty of genocide or any of the other acts enumerated in article III.' In 2003, Rwanda adopted specific legislation: Law no. 33bis/2003 of 9 September 2003, repressing the crime of genocide, crimes against humanity and war crimes.

11 For an analysis of this law and its implementation (which is beyond the scope of this piece), see Digneffe and Fierens, supra note 8, at 64-73. Concerning the temporal application of the law, which will be identical for crimes before gacaca courts, in 1996, certain lawmakers proposed that the law punish genocide in general, without regard to limitations, while others argued that since the genocide began before 1990 and continued after 1994, the law should refer to genocide committed from 1959, i.e. the year of the first interethnic massacres. According to government representatives, 1 October 1990 was the date from which many people, particularly Tutsis, were killed. As for 31 December 1994, it was agreed that the genocide had ceased in July 1994, but that massacres were still perpetrated in various parts of the country; 31 December 1994 marked the end of all massacres. 
accomplices did it take to kill them all? Some say it might have been 4,000,000. The country numbered approximately 7,000,000 inhabitants before April 1994. Subtracting those 1,000,000 victims, as well as young children, the entire adult population is potentially guilty. Others argue that groups of killers were comparatively few in number and that each one could have assassinated an average of 200 people, for example. If so, there are approximately 50,000 individuals to try. Within these two extremes, it is exceedingly difficult to evaluate how many people should be held accountable before local courts, but their number will no doubt come to the tens of thousands. Since the gacaca process began in March 2005 throughout the country, the number of individuals implicated by witness testimony has increased considerably. There may be over $1,000,000$ cases to try. ${ }^{12}$

The idea of establishing gacaca courts crystallized in 1998, to address the practical challenge of prosecuting so many people in a traumatized country, devastated by the civil war and then the conflict in the Democratic Republic of the Congo, in a state where the social fabric is ravaged, where the authorities have many reasons to view the support of the international community with a sceptical eye.

However, expectations regarding such courts also evolved over the years. In the immediate aftermath of the civil war, the authorities and the survivors wished to have those who had committed the atrocities punished. The drive for such punishment, maybe even vengeance, spurred the public execution, on 24 April 1998, of the 22 first accused who had been convicted and received the death sentence. The authorities realized, however, that the unprecedented situation in Rwanda meant they could not wait for all perpetrators to be convicted. Keeping the vast majority of them in prison without a trial proved to be simply unthinkable. From a highly prosaic point of view, tending to the detainees came at great expense to the state. ${ }^{13}$ Victims suffered great setbacks regarding reparations, as was the case with previous genocides. Perpetrators were insolvent and though the specialized chambers frequently condemned the state, this had but symbolic value, since none of those decisions was enforced. ${ }^{14}$ In a country where perpetrators would necessarily be again living alongside their own victims, the rehabilitation of criminals became a pressing objective and warranted some form of reconciliation.

12 See in this article, infra, 2.B.

13 According to the former department of 'gacaca courts', within the Supreme Court, the state spent 2,000,000,000 Frw of its budget for 1998 solely on purchasing food for the detainees. This amount, even though it took up two-thirds of the budget of the Ministry of Justice, still had to be supplemented by a substantial contribution from the ICRC. In 1999, 1,500,000,000 Frw was spent on food, i.e. half the Ministry's budget of 3,800,000,000 Frw; see http://www.inkiko-gacaca.gov.rw/pdf/solution.pdf (visited 29 April 2005).

14 State agents had obviously received orders not to appear or not to provide conclusions. All judgments against the state were adopted by default. See Digneffe and Fierens, supra note 8 , at $69-70$. 
6 of $24 \quad J I C J 3$ (2005)

The idea of resorting to 'participative' justice, supposedly inspired by traditional justice 'rendered on the lawn, ${ }^{15}$ had been voiced during the colloquium held in Kigali from 31 October to 3 November 1995, on 'The Struggle Against Impunity: A Dialogue for National Reconciliation'. At the time, it was deemed to be inopportune and, thus, rejected. However, from May 1998 to May 1999, a series of meetings were held by the President of the Republic with the main administrative and political authorities, at the 'Urugwiro Village'. Tribunals drawing on Rwandan culture and adapting to the specific issues raised by the genocide were thus instituted.

Within a 'workshop' organized for members of parliament in May and June of 1996, the incumbent Minister of Justice presented the main reasons justifying the creation of gacaca courts. They can be summarized as follows: (i) establishing the truth on the number and identity of the victims as well as their lost possessions; (ii) punishing all those who bear a part of responsibility for the events of 1994; (iii) speeding up trials and simplifying judicial procedures; (iv) encouraging the population to participate in the administration of justice; (v) facilitating the gathering of evidence and decreasing travel for witnesses; (vi) reconciling Rwandans on the basis of such truth and the punishment of perpetrators. $^{16}$

Such objectives were also incorporated in the Preamble of the new law, in an attempt to give them concrete meaning. After somewhat brief legislative debates, lawmakers adopted Organic Law no. 40/2000 of 26 January 2001, providing for the creation of gacaca courts and the organization of prosecutions of crimes constituting the crime of genocide or other crimes against humanity, committed between 1 October 1990 and 31 December $1994 .{ }^{17}$ It was amended six months later by Organic Law no. 33/2001 of 22 June 2001. ${ }^{18}$ Finally, due to serious obstacles in implementing the law, and before a single judgment had even been handed down by gacaca courts, it was revised and replaced by Organic Law no. 16/2004 of 19 June 2004, establishing the organization, competence and functioning of gacaca courts charged with prosecuting and trying the perpetrators of the crime of genocide and other crimes against humanity, committed between 1 October 1990 and 31 December 1994.

15 Gacaca literally means grass, the lawn, and refers to the meeting of neighbours in front of a house. On the current gacaca courts, see F. Nzanzuwera, 'Les juridictions "gacaca”, une réponse au génocide rwandais ou le difficile équilibre entre châtiment et pardon', in L. BurgorgueLarsen (ed.), La répression internationale du génocide rwandais (Bruxelles: Bruylant, 2003), at 109-119).

16 Letter from the Vice-President of the Transitional National Assembly no. 105/AN/96 of 12 June 1996 and records of the Transitional National Assembly nos 208/AN/96, 210/AN/96-213/AN/ 96, 728/AN/2000 and 729/AN/2000 (unpublished).

17 Journal officiel, 15 March 2001. A presidential decree was adopted after the law: presidential decree no. 12/01 of 26 June 2001, organizing the election of members of gacaca courts. See also presidential decree no. 26/01 of 10 December 2001, concerning alternative sentences to prison and community service.

18 Journal officiel, 15 July 2001. 
Initially, it envisioned four levels of courts: ${ }^{19}$ one gacaca court for the cell, a gacaca court for the sector, and one for appeals at the level of each remaining sector. ${ }^{20}$

It must be pointed out that gacaca courts cannot exercise jurisdiction over individuals accused of the most serious crimes; those covered by 'category 1 ' in Article 51 of the current law ${ }^{21}$ fall under the jurisdiction of ordinary courts. ${ }^{22}$ Therein lies a first paradox. If gacaca courts provide adequate guarantees and if they can attain the social goal ascribed to them, why not include first-category crimes in their jurisdiction? One argument is that the individuals in question are, by the serious nature of their acts, 'irretrievable' to an extent, and that reconciliation and rehabilitation prove to be irrelevant in such cases. But it seems that lawmakers opting for such exclusion only fuelled doubts as to the integrity of the new judicial system. Gacaca courts cannot impose the death penalty. ${ }^{23}$ Does this indicate that they did not wish to remove the threat of that punishment for the perpetrators of the most serious crimes?

Lastly, it should be recalled that the Military Tribunal and the Military High Court exercise jurisdiction over members of the military. ${ }^{24}$ Since 1994 , these courts' activities, which include trials for acts committed during the genocide, have garnered surprisingly little interest from politicians, the international community, non-governmental organizations and lawyers in general. ${ }^{25}$

\section{The New Constitutional Framework}

To better address the issues raised by the 'gacaca laws', it is necessary to recall that Rwanda adopted a new Constitution on 4 June $2003,{ }^{26}$ i.e. during the

19 'A "gacaca court" is established in each cell, each sector, each district or city and in each province of the Rwandan Republic' (Art. 3 of Organic Law no. 40/2000, 26 January 2001, setting up gacaca courts and organizing prosecutions for offences constituting the crime of genocide and crimes and humanity, committed between 1 October 1990 and 31 December 1994).

20 Article 3 of Organic Law no. 16/2004. There are 9,010 cells and 1,545 sectors in Rwanda.

21 See infra in this article, 2.A.4.

22 Article 2, § 2, of Organic Law no. 16/2004.

23 Only certain individuals falling within category 1 may be sentenced to death. Under Art. 72 of Organic Law no. 16/2004, defendants within the first category who refused to have recourse to confess, plead guilty, repent and apologize, as stipulated under Art. 54 of the organic law, or whose confession, plea of guilt, repentance and apologies have been rejected, incur a death penalty or life imprisonment. Defendants in the first category who confess, plead guilty, repent and apologize incur a prison sentence ranging from 25 to 30 years maximum.

24 Articles 154 and 155 of the Constitution of 4 June 2003.

25 Rwandan military justice, which received substantial financial aid from the USA and Great Britain, opened 843 investigations in 1999; 295 trials were held; 58 individuals were acquitted; 28 sentenced to death; and 207 sentenced to prison for periods of one month up to life. It is difficult to evaluate how many of these cases concerned former soldiers of the RAF accused of genocide, how many involved soldiers of the RPA accused of human rights violations, and how many related to ordinary crimes or offences against military discipline; see Human Rights Watch, http://www.hrw.org/french/reports/rwfr/rwfr-10.htm\#P198_47798 (visited 29 April 2005).

26 The Constitution was adopted by referendum on 26 May 2003, as confirmed by the Supreme Court in its decision no. 772/14.06/2003, handed down on 2 June 2003. 
8 of $24 \quad J I C J 3$ (2005)

creation of the people's courts. The Constitution draws on the main human rights treaties and institutions of Western democracies. It also states that it harbours the same goals as gacaca courts, while redesigning their legal framework. The Preamble aims to eradicate ethnic, regional and any other form of divisions; promote national unity and reconciliation; and build a state governed by the rule of law, based on respect for fundamental human rights, pluralistic democracy, equitable power sharing, tolerance and resolution of issues through dialogue. It reaffirms the privilege of having one country, a common language, a common culture and a long-shared history, which ought to lead to a common vision of their destiny; considers it necessary to extract positive values from their centuries-old history, which characterized their ancestors and that must found the existence and development of the Nation; upholds human rights ${ }^{27}$ and equal rights between Rwandans, and between men and women. Article 9 of the Chapter on Fundamental Principles provides that the State of Rwanda commits itself to promoting the following principles: (i) fighting the ideology of genocide and all its manifestations; (ii) eradicating ethnic, regional and other divisions and promotion of national unity; (iii) equitable sharing of power; (iv) building a state governed by the rule of law, a pluralistic democratic government, equality of all Rwandans and between women and men reflected by ensuring that women are granted at least 30 per cent of posts in decision-making organs; (v) building a state committed to promoting social welfare and establishing appropriate mechanisms for ensuring social justice; (vi) promoting the constant quest for solutions through dialogue and consensus.

The Constitution also enshrines the existence of gacaca courts, referred to as 'specialized courts', and prohibits the creation of special courts. ${ }^{28}$ In addition, it provides for the adoption of a future law establishing a National Service which enjoys administrative and financial autonomy, charged with the follow-up, supervision and coordination of the activities of gacaca courts. Such law would determine its duties, organization and functioning. ${ }^{29}$

Individual freedom is guaranteed by the state. No one shall be subjected to prosecution, arrest, detention or punishment on account of any act or omission which did not constitute a crime under the applicable law at the time it was committed. The right to be informed of the nature and cause of

27 The preamble explicitly refers to the UN Charter of 26 June 1945, the Convention on the Prevention and Punishment of the crime of Genocide of 9 December 1948, the Universal Declaration of Human Rights of 10 December 1948, the International Convention on the Elimination of All Forms of Racial Discrimination of 21 December 1965, the International Convention on Civil and Political Rights of 19 December 1966, the International Covenant on Economic, Social and Cultural Rights of 19 December 1966, the Convention on the Elimination of all Forms of Discrimination against Women of 1 May 1980, the African Charter of Human and Peoples' Rights of 27 June 1981 and the Convention on the Rights of the Child of 20 November 1989.

28 See Art. 143.

29 See Art. 152 and Law no. 8/2004, establishing the organization, functioning and competence of gacaca courts. 
charges, and the right to defence are absolute at all levels and degrees of proceedings before administrative, judicial and all other decision-making bodies. $^{30}$ Every person accused of a crime shall be presumed innocent until his or her guilt has been conclusively proven in accordance with the law, in a fair and public hearing during which all necessary guarantees for the defence have been respected. Nobody shall be denied the right to appear before a judge, competent in law, to hear his or her case. ${ }^{31}$ Nobody shall be punished for acts or omissions that did not constitute an offence under national or international law at the time of commission or omission. Neither shall any person be punished with a penalty which is heavier than the one that was applicable under the law at the time when the offence was committed. ${ }^{32}$ No person shall be subjected to security measures except as provided for by law, for reasons of public order and state security. ${ }^{33}$ The state shall ensure that the exercise of legislative, executive and judicial power is vested in people who possess the competence and integrity required to fulfil the respective responsibilities accorded to the three branches. ${ }^{34}$ The judiciary is independent and separate from the legislative and executive branches of government. It enjoys financial and administrative autonomy. Justice is rendered in the name of the people and nobody may be a judge in his or her own cause. Judicial decisions are binding on all parties concerned, be they public authorities or individuals. They shall not be challenged except through ways and procedures determined by law. ${ }^{35}$ Court proceedings are conducted in public unless a court determines that the proceedings should be in camera on the ground that a public hearing might have an adverse effect on general public order or would outrage public morals. Every court decision shall indicate the grounds on which it is based, be written in its entirety and shall be delivered in open court. Courts apply orders and regulations only where they are not inconsistent with the Constitution and other laws. ${ }^{36}$

Furthermore, Article 13 of the Constitution states that the crime of genocide, crimes against humanity and war crimes do not have a period of limitation, and that revisionism, negationism and trivialization of genocide are punishable by law. ${ }^{37}$ Article 14 indicates that the state shall, within the limits of its capacity, adopt special measures for the welfare of the survivors of genocide who were rendered destitute by the genocide committed in Rwanda from 1 October 1990 to 31 December 1994, the disabled, the indigent and the elderly, as well as other vulnerable groups.

30 See Art. 18.

31 See Art. 19.

32 See Art. 20.

33 See Art. 21.

34 See Art. 60(3).

35 See Art. 140, $\S \S 2-4$.

36 See Art. 141.

37 No specific law has been adopted, despite the fact that a proposal was discussed before parliament from July 2002 to February 2003. 
10 of $24 \quad J I C J 3(2005)$

\section{Questions and Misgivings}

The limited scope of this contribution bars consideration of all the legal, factual and political issues raised by the creation of gacaca courts, even if we only refer to the most recent law. The following problems underscore the extent of the obstacles Rwandan officials continue to face over a decade after the genocide. They also lead to believe that trying tens of thousands of alleged perpetrators of this massacre, while establishing a classical constitutional order or respecting international standards of fair trial, while reverting back to Rwandan traditions, proves to be no easy endeavour.

The aim is not to take stock, but rather raise a number of questions, at a time when gacaca courts are delivering their very first judgments. ${ }^{38}$

\section{A. Legal Issues}

The following analysis discusses a number of legal issues, selected because they directly bear on the will to address a post-genocidal situation by creating original judicial institutions.

\section{1. 'Special' Courts?}

In principle, special courts cannot be created for the purpose of stripping ordinary courts of jurisdiction over certain crimes. Article 143 of the Rwandan Constitution explicitly states so, by forbidding the creation of 'special courts'. This is a highly ambiguous term, since 'special courts' could also refer to courts specialized in certain proceedings, such as military tribunals or juvenile courts, and their institution is not currently in question. It seems preferable to use the terms 'extraordinary courts' for courts whose creation is prohibited by classical democratic constitutions.

Gacaca courts fall squarely within the latter category: they were established to adjudicate acts committed in a time of political crisis, they are temporary by essence and they are composed of judges who were not appointed prior to the facts at hand. ${ }^{39}$

The Canal decision, rendered by the French Conseil d'Etat on 19 October $1962,{ }^{40}$ accepted the creation of an extraordinary court if absolutely necessary, and if such measure has been properly weighed against the public interest. Rwanda could have opted for this solution when creating the gacaca courts, instead of pretending they are only specialized courts.

38 For an analysis of political, historical, legal and criminological issues on the basis of the former legislation and observations until 2002, see Digneffe and Fierens, supra note 8 . The following remarks add to that analysis, or flesh it out with regard to the new law, but are the sole responsibility of the present author.

39 See J. Rivero, Les libertés publiques (Paris: PUF, 1987), 5th edition, at 161-162.

40 M. Long, P. Weil, G. Braibant, P. Delvolvé and B. Genevois, Les grands arrêts de la jurisprudence administrative (Paris: Dalloz, 1999), 12th edition, at 596. 


\section{The Problem of Retroactivity}

Rwandan lawmakers had to explain why acts committed between 1990 and 1994 could be punished by a law adopted after 1996. By ratifying the Convention for the prevention of genocide, Rwanda had in effect prohibited that crime ${ }^{41}$ but, as has been previously said, it did not provide for a specific penalty. And the case was even more complicated for crimes against humanity. The State of Rwanda had ratified the Convention on the Non-Applicability of Statutory Limitations to War Crimes and Crimes Against Humanity of 26 November 1968, but this Convention does not contain specific prohibitions: it simply bars limitation of crimes against humanity, whether committed in time of war or in time of peace, as defined in the Charter of the International Military Tribunal at Nuremberg of 8 August 1945, and confirmed by Res. 3(I) of 13 February 1946 and Res. 95(I) of 11 December 1946 of the General Assembly of the United Nations. The ratification of this Convention did not incorporate crimes against humanity in Rwandan criminal law, much less provide for specific penalties. ${ }^{42}$ Indeed, the treaty only contains the duty for States Parties, in accordance with their own constitutions, to adopt the necessary legislative measures, but it does not provide as such for integration in national systems itself. The Preamble of the law on gacaca courts states that the crime of genocide and crimes against humanity are provided for by the Geneva Convention of 12 August 1949 relating to protecting civil persons in wartime and the Additional Protocols, but neither do these treaties address the crimes as such, nor do they impose the establishment of penalties in national law.

To avoid allegations of retroactivity, and particularly a violation of the principle of nulla poena sine lege, Organic Law no. 08/96 of 30 August 1996 required the acts committed to be doubly prohibited, both by the Rwandan penal code

41 International norms have direct legal effect in the Rwandan system and primacy over national law. Certain international instruments had formerly been held as superior to the Constitution itself. Article 17 of the Protocol on various issues and final provisions in the Fundamental Law of 5 May 1995 indicates such primacy: 'Concerning fundamental rights and freedom, the principles contained in the Universal Declaration of Human Rights of 10 December 1948 have primacy over the corresponding principles in the Constitution of the Republic of Rwanda of 10 June 1991 in case of conflict' (unofficial translation). Today, however, the Constitution's primacy is upheld. Article 190 of the Constitution of 4 June 2003 states that international treaties and agreements which have been conclusively adopted are superior, from their publication in the Official Journal, to organic and ordinary laws, on condition of their performance by the other party. The Constitution is no longer referred to.

42 Customary international law could have been invoked to justify the prohibition on crimes against humanity, although this argument prompts discussions over the existence of such customary nature. The prohibition was established in 1994, though these crimes were only included twice, in the Charters of the International Military Tribunals at Nuremberg and for the Far East. For an opposing view, see J. Verhoeven, 'M. Pinochet, la coutume internationale et la compétence universelle', Journal des tribunaux (1999) 311. 
and the organic law, itself referring to international law. ${ }^{43}$ The reasoning stood as follows: the 1977 Rwandan Penal Code incriminated acts equivalent to genocide or crimes against humanity, but under different appellations. Thus, it was put forward that punishing such acts with the sentences provided for in the code would suffice to counter retroactivity.

The argument's weakness is immediately apparent. Applying penalties from the Penal Code to acts prohibited elsewhere than in the Code bears more resemblance to legalistic block-building than respect for the principle of non-retroactivity. A genocide or crime against humanity does not contain the same acts as those laid out in the Penal Code. The overarching social necessity of going beyond the traditional incriminations of murder, assault and battery or rape is one such clue of this. The point, as it was in 1945, is to adopt different prohibitions precisely because what happened went beyond the penal code. Furthermore, the international prohibition, which purports to express the exceptional gravity, even supreme gravity, of certain crimes, calls on judges to inflict particularly severe penalties, and thus engenders retroactive effects.

Organic Law no. 40/2000 of 26 January 2001, establishing the creation of gacaca courts, also contained a double prohibition, phrased in rather awkward terms inherited from the Organic Law of $1996 .{ }^{44}$ Article 1 stated that the purpose of this organic law is to organize the putting in trial of persons prosecuted for having, between October 1, 1990 and December 31, 1994, committed acts qualified and punished by the penal code and which constitute: a) either crimes of genocide or crimes against humanity as defined by the Convention of December 9, 1948 preventing and punishing the crime of genocide, by the Geneva Convention of August 12, 1949 relating to protecting civil persons in wartime and the Additional Protocols, as well as in the Convention of November 26, 1968 on imprescriptibility of war crimes and crimes against humanity; b) or offences aimed at in the penal code which, according to the charges by the Public prosecution or the evidences for the prosecution or even what admits the defendant, were committed with the intention of perpetrating genocide or crimes against humanity'.

Organic Law no. 16/2004 of 19 June 2004 abandoned the principle of double incrimination. Article 1 now reads as follows: 'This Organic Law establishes

43 'The purpose of this Organic Law is to organize the putting in trial of persons prosecuted for having, between October 1, 1990 and December 31, 1994, committed acts qualified and punished by the penal code and which constitute: a) either crimes of genocide or crimes against humanity as defined by the Convention of December 9, 1948 preventing and punishing the crime of genocide, by the Geneva Convention of August 12, 1949 relating to protecting civil persons in wartime and the additional protocols, as well as in the Convention of November 26, 1968 on imprescriptibility of war crimes and crimes against humanity; b) or offences aimed at in the penal code which, according to the charges by the Public prosecution or the evidences for the prosecution or even what admits the defendant, were committed with the intention of perpetrating genocide or crimes against humanity', Art. 1 of Organic Law no. 08/96.

44 The ambiguity stems from the unfortunate juxtaposition of par. 1 and lit. b, which reads: '....acts qualified and punished by the penal code and which constitute... offences aimed at in the penal code.... 
organization, competence and functioning of gacaca courts charged with prosecuting and trying the perpetrators of the crime of genocide and crimes against humanity committed between October 1, 1990 and December 31, 1994, or other crimes provided for in the penal code of Rwanda, but according to the declarations of the Public Prosecution or testimonies against the defendant, as well as in the defendant's confessions in relation to criminal acts carried out with the intention of committing genocide or crimes against humanity' Not without a measure of contradiction to Article 1, Article 3 no longer contains an explicit reference to the penal code: "[gacaca courts] are in charge of putting on trial, within the limits established by this organic law, the offences constituting the crime of genocide or crimes against humanity committed between October 1, 1990 and December 31, 1994.'

The current law is therefore retroactive, more clearly so than the previous ones, and notwithstanding the fact that Article 18 of the Constitution states the principle under which individuals can only be punished for acts which constituted a crime at the time of their commission.

Accordingly, arguing that the principle of nulla poena sine lege has been or is respected might give way to affirming that the gravity of certain crimes simply outweighs such principle, as the Nuremberg judges implied. ${ }^{45}$

\section{A Material Scope Theoretically Broader than the Genocide of Tutsis}

Under Article 1 of aforementioned Law no. 16/2004, gacaca courts exercise jurisdiction exclusively over acts constituting genocide and other crimes against humanity, or acts perpetrated with the intention of committing genocide or other crimes against humanity. ${ }^{46}$

This wording indicates that such courts could exercise jurisdiction over crimes against humanity, regardless of genocidal intent, if they constitute other crimes against humanity, and over acts of genocide committed against a group other than Tutsis in the established timeframe.

Rumours show that proceedings before gacaca courts will involve the RPA forces that tried to recapture the territory in 1994. The political interpretation of subsequent laws rules out such jurisdiction for gacaca courts, as leaders

45 'It is to be observed that the maxim nullum crimen sine lege is not a limitation of sovereignty, but is in general a principle of justice. To assert that it is unjust to punish those who in defiance of treaties and assurances have attacked neighbouring states without warning is obviously untrue, for in such circumstances the attacker must know that he is doing wrong, and so far from it being unjust to punish him, it would be unjust if his wrong were allowed to go unpunished', Judgment of the International Military Tribunal for the Trial German Major War Criminals: Nuremberg, 14 November 1945-1 October 1946, Vol. 1, available online at: http://www.yale.edu/lawweb/avalon/imt/proc/judlawch.htm (visited 29 April 2005).

46 Which amounts to the same from a criminal perspective as far as genocide is concerned, since attempt and complicity are punishable as acts of genocide. See Art. 3 of the Convention on the Prevention and Punishment of the crime of genocide of 9 December 1948. 
14 of 24 JICJ 3 (2005)

insist it will only be exercised with regard to the genocide of Tutsis. This reading adheres to the lawmakers' intent, but it hardly seems compatible with the text of the article.

\section{Categories $2,3^{\circ}$ and 3 and the Intent to Commit Genocide or Crimes Against Humanity}

Article 51 of Organic Law no. 16/2004 of 19 June 2004 redefines the different categories of alleged perpetrators for the third time, after the laws of 1996 and 2001. It reads as follows:

Following acts of participation I offences referred to in article one of this organic law, committed between October 1, 1990 and December 31, 1994, the accused can be classified in one of the following categories:

First Category: ${ }^{[47]}$

(a) The person whose criminal acts or criminal participation place among planners, organizers, imitators, supervisors and ringleaders of the genocide or crimes against humanity, together with his or her accomplices;

(b) The person who, at the time, was in the organs of leadership, at the national level, at the level of the Prefecture, Sub-Prefecture, Commune, in political parties, army, gendarmerie, communal police, religious denominations or in militia, has committed these offences or encouraged other people to commit them, together with his or her accomplices;

(c) The well known murderer who distinguished himself or herself in the location where he or she lived or wherever he or she passed, because of the zeal which characterized him or her in killings or excessive wickedness ${ }^{48}$ with which they were carried out, together with his or her accomplices;

(d) The person who committed acts of torture against others, even though they did not result into death, together with is or her accomplices;

(e) The person who committed acts of rape or acts of torture against sexual organs, together with his or her accomplices;

(f) The person who committed dehumanizing acts on the dead body, together with his or her accomplices.

The Prosecutor General of the Republic publishes, at least twice a year, a list of persons classified in the first category, forwarded by Gacaca Courts of the Cell.

47 The first was defined as follows under Organic Law no. 08/96, which had introduced these categories: a) persons whose criminal acts or whose acts of criminal participation place them among the planners, organizers, instigators, supervisors and leaders of the crime of genocide or of a crime against humanity; b) persons who acted in positions of authority at the national, prefectoral, communal, sector or cell level, or in a political party, or fostered such crimes; c) notorious murderers who by virtue of the zeal or excessive malice with which they committed atrocities, distinguished themselves in their areas of residence or where they passed; d) persons who committed acts of sexual torture. The post-war American tribunals had already used categories for trying Japanese criminals.

48 One can only wonder what constitutes 'unexcessive' malice. 
Second Category:

(1) The person whose criminal acts or criminal participation place among killers or who committed acts of serious attacks against others, causing death, together with his or her accomplices;

(2) The person who injured or committed other acts of serious attacks with the intention to kill them, but who did not attain his or her objective, together with his or her accomplices;

(3) The person who committed or aided to commit other offences (against) persons, without the intention to kill them, together with his or her accomplices.

Third Category:

The person who only committed offences against property. However, if the author of the offence and the victim have agreed on their own, or before the public authority or witnesses for an amicable settlement, he or she cannot be prosecuted.

An analysis of the different variations in the Organic Law with regard to such categories since 1996 is beyond the scope of this contribution. It is worth noting that under Article 1 of Organic Law no. 16/2004, the gacaca courts exercise jurisdiction ratione materiae over crimes carried out 'with the intention of committing genocide or crimes against humanity'. Such intent may very well be present for acts falling within categories 1 through 2 , and $2^{\circ}$. But, as regards the alleged perpetrators of criminal acts or criminal participation with intent of causing death (categories $2,3^{\circ}$ ), and those accused of offences against property (category 3), the article requires a finding of the intent to commit genocide or crimes against humanity in each instance. Under the principle of strict construction of criminal law, the current law would subtract a large number of individuals concerned by the latter categories from the jurisdiction of gacaca courts. Article 1 of Organic Law no. 08/96 of 30 August 1996 mentions crimes 'in connection with the events surrounding the genocide and crimes against humanity', which bears rather more resemblance to the current intention of lawmakers. This wording could have been preserved.

\section{Fair Trials and the Rights of the Defence}

The most obvious shortcoming of the gacaca laws lies in their lack of respect for rights of the defence. The nature and functioning of gacaca courts are not compatible with minimum standards of fair trials, as enshrined in the International Covenant on Civil and Political Rights (ICCPR) (Articles 9 and 14) or the African Charter on Human and Peoples' Rights (Articles 6, 7 and 26), which Rwanda has ratified. The UN High Commission for Refugees, ${ }^{49}$ the UN High Commission for Human Rights, ${ }^{50}$ and even Human Rights

49 UN High Commission for Refugees, Background Paper on the Human Rights Situation in Rwanda (Geneva, January 2000).

50 Economic and Social Council of the UN, Situation de droits de l'homme au Rwanda, Resolution of the Human Rights Commission (1999/20, 23 April 1999). 
16 of 24 JICJ 3 (2005)

Watch ${ }^{51}$ already expressed their concern over this issue in 1999. The Council of the European Union had 'encouraged the Rwandan government to establish the gacaca system while ensuring respect for international human rights standards. 52

Gacaca courts hold broad competences, similar to those of ordinary courts', exercising attributes of investigation, prosecution and judgment. ${ }^{53}$ At the trial phase, they can issue subpoenas, proceed with search and seizure, adopt temporary measures, issue arrest warrants and order provisional detention or liberation. At the judgment and sentencing phases, gacaca courts acquit or convict individuals, pronounce sentences and allow compensation for victims. Does the right to a fair trial not preclude functional overlap between investigative or prosecutorial powers and trial powers?

Beyond the objective impartiality of gacaca courts, what of their subjective impartiality, i.e. that which appears in the eyes of the accused? ${ }^{54}$

Quid of the principle, also enshrined in the legal decree providing for the organization of the judiciary, according to which a judge cannot make findings based on evidence obtained in a personal capacity ${ }^{55}$

The Cell's seat ${ }^{56}$ collects files sent by the prosecution, takes note of offers to supply evidence or testimony, proceeds with investigations and adjudicates offences committed by perpetrators falling within the fourth category. Will the accused be allowed to consult his case file before the hearing? If so, who will help him or her read it, if he or she cannot do so him or herself? The law remains silent on this point.

Articles 64 and under of Organic Law no. 16/2004 establish detailed procedures for hearings. It is worth noting, among other aspects, that 'any interested

51 Human Rights Watch, Rwanda: de la recherche de la sécurité aux abus des droits de l'homme (New York, April 2000).

52 Council Common Position of 18 September 2000 on Rwanda, 2000/558/CFSP, Official Journal L236 (20 September 2000). See also, more recently, Council Common Position of 21 October 2002 on Rwanda and repealing Common Position 2001/799/CFSP, Official Journal L285 (23 October 2002), at 3. The Council 'welcomes the official launch of gacaca tribunals and encourages the Government of Rwanda to monitor the forthcoming procedures in close cooperation with national and international non-governmental organization; ... encourages the Government of Rwanda and the Supreme Court to ensure that gacaca justice is administered in line with international human rights standards; ... also encourages the gacaca courts to establish clemency in general as a basic working principle and to safeguard rights guaranteed by law both to the accused, particularly as regards defence and appeals, and to civil parties'.

53 See Art. 39 of Organic Law no. 16/2004.

54 See the theory of the appearance of justice developed by the European Court of Human Rights: 'justice must not only be done: it must also be seen to be done'; among others, see Judgment of 28 June 1984, Campbell and Fell v. United Kingdom, available online at: http://www.echr.coe.int (homepage) (visited 29 April 2005).

55 Decree-Law no. 06/82 of 7 January 1982, relating to the status of judicial personnel (Journal Officiel, 15 April 1982), Art. 31(1).

56 On the establishment of the seats of gacaca courts, see Arts 5, 8, 14 and 15, 23, 34, 36, 37 of Organic Law no. 16/2004. 
person $^{57}$ may testify, in addition to the members of the General Assembly. The right to remain silent for the accused is not recognized, as he/she must respond to the questions put to him/her, thus triggering a violation of his/her right to a fair trial, as enshrined in Article 14 of the ICCPR.

While accused individuals may present their own defence, they cannot be assisted by counsel or other persons. The fact that interested persons may participate and testify in hearings could somewhat mitigate this serious breach of international standards, but, as such, the right to counsel and, generally, defence rights are not provided for. The right to be defended by an individual wholly distinct from the prosecution, witnesses or judges is nevertheless one of the most universally recognized human rights. Victims cannot be assisted either.

The law does not provide for representation, even for individuals who may have been minors at the time of the acts or victims suffering from serious trauma. One can only imagine how difficult it would be for victims of sexual crimes to have to come and testify in person.

The Rwandan authorities believe or pretend to believe that people's justice is infallible. It is immediately apparent that Rwandans have no more reason to tell the truth than anyone else in a given judicial system; that certain judges in those hills are themselves implicated in the genocide; that potential witnesses have been threatened directly and indirectly; and that, at times, the genocide's effectiveness was such that perpetrators, co-perpetrators and accomplices could simply establish gacaca courts among themselves.

The Rwandan authorities have adopted contradictory responses to these issues, either by asserting the gacaca courts' conformity with obligations under international law, or by stating that such conformity is irrelevant given the particular context. If the latter is true, Rwanda should have at least notified its intent to override provisions of the ICCPR under Article 4.

\section{B. Issues Concerning the Facts}

Exhorting supposedly traditional modes of conflict resolution in Rwanda provides no guarantees, and the nature of 'persons of integrity' to be elected as judges remains an issue. Further, the executive, rather than gacaca courts, adopts decisions concerning alleged perpetrators. Lastly, the length of proceedings does not bode well for their outcome, even after the process was considerably broadened on 10 March 2005.

\section{The Reference to Tradition}

The gacaca process supposedly harkens back to Rwandan tradition. It would be more accurate to state that it endeavours to legitimize a hereto unheard-of 
18 of $24 J I C J 3(2005)$

attempt at people's justice, which aims to deal as rapidly as is feasible with an avalanche of cases, rather than to draw upon cultural specificities.

Charles Ntampaka, one of the leading experts on Rwandan customary law, observed that the traditional system of conflict resolution did not include any written rules; remained wary of legal prescriptions that adjudicate and convict; was closely related to the family unit; favoured the role of "head of the family; involved forms of collective responsibility; did not promote equality; gave priority to community interests over individual rights; often deemed confessions to be a form of provocation; and drew on the sacred and the religious. $^{58}$

Such characteristics are in stark contrast to the present gacaca courts and their functioning. The only resemblance lies in the fact that the institutional framework for conflict resolution involves local and non-professional judges, and, even then, they are elected in the reinvented gacaca system, whereas traditional judges were appointed by consensus between the concerned parties. The present gacaca court arises from a complex written law; is not traditional; rests on a supposedly legal basis; confers no privileges on family members; ${ }^{59}$ allegedly respects individual rights; favours confessions; and does not include any references to religion. ${ }^{60}$

\section{The Status of 'Persons of Integrity' (Inyangamugayo)}

Implementing the planned legal framework gives rise to complex problems. Aforementioned issues of qualification present such obstacles, along with categorization and, generally, the complex nature of a long-winded and experimental law which nevertheless relates to judges who are often illiterate and lacking legal education. ${ }^{61}$

The authorities provide for minimal training of 'persons of integrity', but one can doubt whether it enables effective implementation of a new and complicated law, which could provoke heated, even violent, debate. As judges receive no payment, the quorum prescribed by law is met with increasing difficulty in

58 C. Ntampaka, 'Le retour à la tradition dans le jugement du génocide rwandais: le gacaca, justice participative', 48 Bulletin de l'Académie royale des sciences d'Outre-mer (2002) 419-455. From the same author, 'Le gacaca rwandais, une justice répressive participative', 6 Actualité du droit international humanitaire. Les dossiers de la Revue de droit pénal et de criminologie (2001) 211-225. F. Reyntjens, 'Het recht van het grasveld: statelijk en niet-statelijk strafrecht in Rwanda', in Liber Amicorum Jules D'Haenens (Gand: Mys and Breesch, 1993), $269-275$.

59 On the contrary, members of gacaca courts cannot sit in hearings or participate in decisions on cases concerning a family relative; see Art. 10 of Organic Law no. 16/2004.

60 Except for oaths of 'persons of integrity'; see Art. 9 of Organic Law no. 16/2004: '... So help me God.'

61 Only members of the coordination committee elected for each gacaca court need to be able to read and write kinyarwanda. See Art. 11 of Organic Law no. 16/2004. 
the experimental phase of implementation, due to rising poverty, and it has thus been reduced. ${ }^{62}$ The risk of corruption is also rife.

\section{3. 'Solidarity Camps' and Liberation by the Executive}

Under orders of the President, Rwandan police and authorities began transferring detainees to 'solidarity camps' (ingando) at the beginning of 2004. Prisoners are to follow 'reeducation courses' in these camps for a number of weeks, before reintegrating into their communities. ${ }^{63}$

At the same time, about 20,000 individuals, of whom most had confessed, were temporarily set free, along with 2,000 ill or aged detainees. Three per cent were then re-incarcerated following new testimonies related to their crimes. The freed individuals have not been granted amnesty, as they are to be tried at a later date.

Two problems arise, other than the nature and precise function of solidarity camps. First, on what legal basis can the executive order these liberations, given that such power belongs to gacaca courts of the cell? ${ }^{64}$ And, secondly, will these individuals actually be tried, or is this the first step towards a de facto amnesty?

\section{Delays in Implementation}

Public information campaigns were set in motion from 2001, via radio, Rwanda's main media outlet, and television.

'Pre-gacaca' hearings have been held in various places. They aimed to establish case files for a number of detainees, and then presented approximately 800 prisoners, for whom there are only a few elements proving their participation in the genocide, to the people. About 200 among them were granted temporary release. These 'pre-gacaca' hearings lack legal basis.

Alleged perpetrators were encouraged to confess and plead guilty.

Approximately 250,000 'persons of integrity' were elected between 4 and 7 October 2001. The participants in the gacaca process received general training and a manual was drafted for them.

Gacaca courts began functioning from June 2002 in 12 'pilot sectors', then 106 others in November $2002 .^{65}$

62 Currently, gacaca courts can only sit in session if at least seven of its members are present. Previously, 15 members were needed.

63 See Human Rights Watch, Rwanda: De la Recherche de sécurité aux abuses des droits de l'homme (Camps de solidarité), available online at http://www.hrw.org/french/reports/rwfr/rwfr-14.htm (visited 29 April 2005).

64 See Art. 39(8) of Organic Law no. 16/2004.

65 For more details on its implementation until 2002, see Digneffe and Fierens, supra note 8, at $104-116$. 
20 of $24 \quad J I C J 3(2005)$

According to the Rwandan government, proceedings were launched in June 2004, immediately following the promulgation of the new law, in all courts, i.e. 9,010 cells and 1,545 sectors. However, Lawyers Without Borders and Penal Reform International, which monitor the daily proceedings of gacaca courts by regularly attending hearings across the country, have not reported on their observations since July 2003. ${ }^{66}$

The first 'pilot' gacaca courts, set up in 2003, were finally entering into judgment phase at time of writing. Thirty-four decisions have just been handed down, ${ }^{67}$ ranging from acquittals to sentences of up to 30 years in prison. At the same time, trials are officially under way in 751 other gacaca courts; 8,262 should be operational next year. Problems have accrued due to this very implementation, and the number of individuals implicated in testimonies delivered through these proceedings could come to over 1,000,000. The authorities place the gacaca process's completion at three to five years, but this time-line does not seem realistic. Furthermore, the authorities could fall into political strife, as 668 incumbent administrative or military leaders, including the prefect for the region of Ruhengeria and two of the most famous former officers of the Rwandan Armed Forces (RAF), have allegedly been accused before gacaca courts; 126 among them have been relieved of their duties, pending trial. ${ }^{68}$

Trials before ordinary courts for alleged perpetrators falling with the first category do seem to be taking place.

\section{Conclusion: An Overly Ambitious Gacaca Law?}

The main weakness of the gacaca laws lies perhaps in their very ambition. They strive to accomplish much more than the criminal conviction of perpetrators, by aiming to shed light on the truth of what happened, to recreate the social fabric and promote reconciliation. According to the Preamble of Organic Law no. 16/2004, which departs little from previous laws, the gacaca process aims to:

... achieve justice and reconciliation in Rwanda, and thus to adopt provisions enabling rapid prosecutions and trials of perpetrators and accomplices of genocide, not only with the aim of providing punishment, but also reconstituting the Rwandan Society that had been destroyed by bad leaders who incited the population into exterminating part of the Society; ... it is important to provide for penalties allowing convicted prisoners to amend themselves and to favour their reintegration into the Rwandan Society without jeopardizing the people's normal life.

66 See http://www.asf.be and http://www.penalreform.org (visited 29 April 2005).

67 The author does not yet have access to them.

68 On these factual elements, see press releases by Hirondelle in March 2005, available online at: http://www.hirondelle.org (visited 29 April 2005) and International Justice Tribune, no. 23, available online at: http://www.justicetribune.com (visited 29 April 2005). 


\section{A. Criminal Courts Do Not Promote Reconciliation}

At any rate, courts, especially criminal ones, rarely enable reconciliation, particularly when the crimes in question are among the most serious imaginable. Courts seldom amend relations between the perpetrators and victims of benign offences, so what can be said for genocide or crimes against humanity?

It is not easy to discern how Rwandan tradition, or supposed reference to custom, might provide an outcome related to criminal law, which, at any rate, it cannot attain by itself. On the contrary, traditional gacaca is geared towards conciliation-not reconciliation-rather than judgment. ${ }^{69}$ Therein lies the difference between the old and new gacaca: tradition is cloaked in the mantle of a criminal trial, with a strict and written procedure, and leading to a supposedly legal judgment.

\section{B. Between Vengeance and Pardon}

The justice of man always lies between two extremes: vengeance and pardon.

\section{A Just Distance}

With vengeance, victims themselves inflict what they have suffered upon the perpetrator. Recollection of the crime is embedded in a violence that breeds another, in the exact reversal of a power paradigm. It is characterized by the absence of a just distance ${ }^{70}$ no rule of law, no moral interposes itself between the perpetrator and the victim, no third party, no tribunal divides the adversaries. Society may also wish to exact revenge. In this respect, public opinion, international included, presents a danger, as it constitutes the main vector for collective vengeance. Nietzsche, who was by no means sentimental, wrote that 'liberating man from thoughts of vengeance is the bridge for higher hopes, and the rainbow after long storms. ${ }^{71}$ Criminal law provides for a punishment which delineates a space between victims and perpetrators, between society and the perpetrator, by the intervention of a third party-the judge. Punishment is socialized, meted out in the name of society, not the victim. Society responds to the commission of an offence, to the injury wrought by a perpetrator, by inflicting a form of suffering: imprisonment, fines, even the death penalty. The emotional side of vengeance gives way to a rational side: moral retribution, re-establishing order, perhaps educating the perpetrator, perhaps preventing recurrence, perhaps showing an example, perhaps protecting society. Such are the different goals of punishment in criminal law and criminology. The strength of criminal punishment stems from the fact the

69 See Ntampaka, supra note 68, at 424.

70 See P. Ricœur, Lectures 1: Autour du politique (Paris: Seuil, 1991) 176-195.

71 F. Nietzsche, Ainsi parlait Zarathoustra (Paris: Aubier-Flammarion [bilingual edition] 1969), at 221. 
22 of 24 JICJ 3 (2005)

perpetrator owes it to society, at times to the victim, but also to himself. It enshrines his rationality and freedom. Kant, among others, insisted on this $^{\text {aspect. }}{ }^{72}$

Furthermore, repression remains unacceptable for perpetrators and their families. The different protagonists continue to ignore each other, even hate each other. The weakness of the gacaca process might lie in the fact that it still borders closely on vengeance, or at least revenge, to the point of forgetting the depth of victims' suffering, not only in the crime committed against them, but also in the void around them created by violence, and their absolute solitude. Such solitude is psychological, social and metaphysical, since the sublime has forsaken them forever. Criminal judgments present the advantage, if it can be so named, of cleaving a legal, social and symbolic distance between victims and perpetrators, and clearly stating that both good and evil exist.

\section{A Purely Legal Truth}

Can the gacaca system provide restorative justice, recreate the link between victims and perpetrators within the rule of law, beyond punishment? Political authorities consistently uphold, no doubt correctly, the need to link truth to justice. In this respect, to judge is also to name: a perpetrator, a victim, a past, a future. Justice and truth share intimate bonds, ${ }^{73}$ but such justice and truth can only be judicial and criminal. They will only transcribe the horror and the suffering, inflict sentences of improbable virtue, and attempt to acknowledge victims. It cannot be infallible. The truth uncovered by gacaca courts will probably only serve to end discussions over what happened, through adjudication. Historians, particularly, should endeavour endlessly to better reveal such truth. Victims will continue to suffer, as judicial reckoning will be that of the conviction rather than the trauma. This might only be exacerbated because discussing it will remain exceedingly difficult. Revisiting such memories before courts is itself painful. Such memories do not allow for grieving, for finding peace. Institutional justice, including gacaca, can only offer an ersatz of justice, a truncated truth, an uncelebratory memory. It is best to acknowledge that fact.

\section{Courts Do Not Foster Reconciliation}

The possibility of reconciliation might finally arise. Only then will the ideas of forward-reaching remembrance, justice as an ideal, refusal of impunity and reconstructing social fabric coalesce. To forgive, to forget past or present punishment, is not to forget history and suffering, whether inflicted or

72 See, in particular, La Doctrine du droit (Rechtslehre): Die Metaphysik der Sitten (1797), ed. by W. Weischedel, Vol. VIII (Berlin: Suhrkamp, 1989), at $314 \mathrm{ff.}$

73 See P. Ricœur, Le Juste (Paris: Esprit, 1995) 193-208. 
endured; on the contrary, remembering pain offers the means and the justification for experiencing hatred and then renouncing such hatred, or, as Paul Ricoeur put it, "breaking the debt. ${ }^{74}$ One can forgive what one remembers and, in this respect, children must be told what came to pass and why, without attempting to gloss over the ethnic problem in Rwanda.

Collective pardon, enshrined in a law, does not exist. Shadows of reconciliation and caricatures of forgiveness are pardon's greatest enemies-its very negation even. They are the lies told by politicians and the law. Amnesty, the first among such lies, continues to be a threat in Rwanda. ${ }^{75}$ Such a decision, legislative in its explicit form, is an institutional amnesty, imposed against all truth and reconciliation. A society cannot exist while deciding that such event did not occur, but the authorities may try to force it to forget. ${ }^{76}$ Clemency, both in a legal and institutional meaning, is the second false form of pardon, granted by the executive for its part. Political and opportunistic, it disregards victims, who have no say in its conferral or refusal.

Tribunals, regardless of their nature, do not find their place in processes of reconciliation, politics, institutions, in the law. Pardons lie at the heart of an interpersonal relationship which goes beyond the law and even morals. ${ }^{77}$ A person who has watched his relatives being tortured and killed before him or who has suffered similar, or even lesser, acts can legitimately refuse to grant pardon. By definition, authentic pardons bear the risk of not being requested or, if they are, being refused. Pardons are never owed; any law which provides for it distorts the notion.

Gacaca courts will fulfil their mission only if they solve the wealth of legal and practical issues which have cropped up. And they will only do so if it is clear at the outset what they can or cannot accomplish. They will not achieve anything else but unsatisfactory procedures with regard to international standards of due process. They will not achieve anything else but a limited judicial truth, desperately needed by Rwandans but which cannot encompass

74 Ibid.

75 It is difficult to conceive of amnesties for a genocide. The Treaty of Lausanne of 1923 nevertheless granted amnesty for the 1915 genocide of Armenians.

76 One of the first and most famous examples is Art. 1 of the Edict of Nantes, signed by Henry IV in 1598 to end the wars of religion involving what would nowadays be viewed as genocide (the massacre of Saint Barthelemy, for example) or crimes against humanity: 'First, that the recollection of everything done by one party or the other between March, 1585, and our accession to the crown, and during all the preceding period of troubles, remain obliterated and forgotten, as if no such things had ever happened. It will not be opportune or allowed for our prosecutors or any other person, public or private, on any occasion at all, to invoke trials or prosecution before any court whatsoever', translated in J.H. Robinson, Readings in European History, 2 Vols (Boston: Ginn, 1906), at 180-183.

77 According to the Rwandan Office for Information (ORINFOR), Madame Domitille Mukantaganzwa, Executive Secretary to the National Service for Gacaca Courts is said to have stated on 30 March 2005: 'Gacaca is a more religious than political programme, as it aims at confession, pardon and reconciliation among Rwandans', available online at: http://www.orinfor.gov.rw/DOCS/Justice21.htm (visited 29 April 2005) (unofficial translation). 
24 of $24 \quad J I C J 3$ (2005)

a deeper truth, elusive and unattainable, that escapes their grasp; nothing more than partial, incomplete remembrance, which will continue to hurt victims; nothing else but a reasonable distance from vengeance, and the improbable reconstruction of an extremely fragile social fabric.

The rest is beyond law and institutions. The law can only provide the circumstances for future reconciliation, which might take place, if at all, elsewhere than before gacaca courts. Rwandan authorities and the international community should accept these limitations and cease grasping at thin air.

It is still better to do justice, albeit unsatisfactorily, than not do justice at all. 